\title{
The Development of Elementary School Mathematics Learning Packages assisted by Manipulative Media: Supporting Qualified and Creative Primary Teacher Candidate Programs
}

\author{
Latri $^{1}$, Johara Nonci ${ }^{2}$, Agusalim Juhari ${ }^{3}$ \\ \{unmlatri2014@gmail.com ${ }^{1}$, agusalimjuhari@gmail.com ${ }^{3}$ \} \\ ${ }^{1,2}$ Elementary Eduaction Program, Faculty of Science Education, UNM, Indonesia \\ ${ }^{3}$ Mathematics Education of STKIP Pembangunan Indonesia, Indonesia
}

\begin{abstract}
This research aimed to support and implement government programs of National Education in preparing Qualified and Creative Primary Teacher Candidates. Specific targets were (1) developing elementary Mathematics learning packages assisted by manipulative media, namely: (a) Student Books, (b) Student Worksheets, (c) Lesson Plan. The research design used modification and adaptation from 4-D model (Define, Design, Develop, and Disseminate), by Thiagarajan, et al (1974). The criteria which used as a reference for implementing the effectiveness of elementary school mathematics learning Packages were: (1) interaction of Student and (2) student learning outcomes. The results shows that the development of learning Package with a 4-D model that has been modified, starting from the front end analysis (Define), the initial design of learning packages (Design), until the trial step of Learning Package (Develop). Implementation and desimination have not been implemented. Elementary mathematics learning Packages assisted by manipulative media on number material are valid, effective, and practical to improve mathematical pedagogy skills of qualified and creative elementary school teachers candidates. The effectiveness of the learning packages meets the effective criteria by: (1) student activities when participating in high learning and (2) the learning outcomes of the teacher candidiates are complete with the average learning outcome is at 77.24 of the ideal score of 100 and the completeness test of the learning outcomes test with grades the probability of one sample t-test is $0.003<0.05$, which means that students' learning outcomes are complete.
\end{abstract}

Keyword: Learning Packages Development, Elementary Mathematics, Manipulative Media

\section{Introduction}

One problem that is often found by elementary school students in learning mathematics is how to understand abstract objects from mathematics itself. Students' understanding of abstract Mathematics objects is considered to be the main concern for Teachers in teaching Mathematics.

There have been many conscious efforts that have been made by teachers / lecturers / researchers in bridging elementary students' understanding of asbtrak objects into concrete objects in mathematics. However, the business has not been considered optimal until now. The indicators used are still poor understanding of elementary school students about (1) the basic concepts of number operations, (2) measurement, and (3) Geometry. Even not a few middle and high school students to date, not too clever in carrying out simple number operations. Of 
course, these problems can not be separated from how students get their learning experience in understanding abstract mathematical objects.

A student in understanding abstract mathematical objects can go through several stages of learning. According to Bruner these stages are enactive, econic and symbolic stages. Enactive stage is the stage of learning to manipulate objects or concrete objects. The ekonic stage is the learning stage using pictures, and the symbolic stage is the learning stage by constructing the construction of concepts and principles through symbols. Learning strategies and approaches that are not in accordance with the stages of student learning cause students to tend to be passive and not enthusiastic. In fact, only a few students can understand so that the knowledge possessed by students is not trace.

Efforts that can be made to address these problems are to prepare creative elementary school teacher candidates who are able to provide learning strategies and introduce concrete media / models that are appropriate to the stages of elementary student learning. For this reason, prospective elementary school teachers need to get qualified learning experiences and get more creative provisions in teaching abstract mathematical objects later.

To realize the above, one of the efforts that can be done is to prepare a learning Packages well and on target. The learning Packages in question is a elementary school mathematics learning Packages that minimizes the abstractness of the mathematical object itself. mathematical abstract objects can be assisted with the help of manipulative media (media that can be flipped, cut, shifted, moved, drawn, sorted, grouped or classified) [1]

Mathematics learning packages assisted by manipulative media are prepared, consisting of Learning Program Plans, Model Books, Model Worksheets, Assessments, and Learning Models that are adapted to Mathematics teaching materials in Elementary schools. The learning packages presented will accommodate elementary mathematics materials. Further problems can be formulated as follows: (1) How is the development of elementary mathematics learning packages assisted by manipulative media in supporting superior and creative elementary school teacher programs? And (2) To what extent are the effectiveness of the SD Mathematics Learning packages assisted by manipulative media that have been developed in Supporting the Superior and Creative Elementary Teacher Program?

\section{Research Methods}

The implementation of this research follows the modified and adapted Four-D [2] development model, which consists of four stages, namely defining, designing, developing, and disseminating.

\section{Defining stage}

The define phase aims to define and define learning requirements before creating an Elementary Mathematics Learning Kit. Determination and determination of learning requirements, starting with an analysis of the objectives and limits of the material to be assessed. Activities in this stage are front end analysis, Student analysis, material analysis, task analysis, and learning objective specifications. 


\section{Design phase}

The design phase is intended to design the Tools and Models of Elementary Mathematics Learning in Basic Mathematics courses. The activities carried out at this stage are team consolidation, media selection, and selection of learning Packages formats.

\section{Development stage}

The development phase is intended to produce prototypes-2, Elementary Mathematics Learning packages and Models. The learning kit has been revised based on the results of the prototype- 1 analysis, input from experts and practitioners as well as the results of the analysis of learning activities. Furthermore, the results of improvements in field trials in the development phase (develop) produce prototype-3, then prototype-3 learning Packages are socialized, so as to produce the final prototype.

\section{Disseminate}

Disseminate phase is carried out by carrying out socialization activities on Elementary Mathematics Learning packages and Models through limited seminar activities involving prospective teachers / lecturers, students, and the public.

\section{Research Location}

This research was conducted in the Elementary Eduaction Program, Faculty of Science Education, Universitas Negeri Makassar.

\section{Data collection technique}

\section{a. Learning packages validation sheet}

The validation sheet of the Elementary Mathematics Learning packageskit is used to obtain data about the results of the validation of experts and practitioners (lecturers) about the learning kit.

b. Observation sheet activities of students

Student activities are recorded through observation to capture supporting data on the effectiveness of the application of learning packages that have been developed.

c. Observation sheet ability of lecturers to manage learning

Observation sheet on teacher's ability to manage learning through the Tools and Models of Elementary Mathematics Learning.

d. Observation sheet implementation of Learning Packagess

The observation sheet of the implementation of the equipment was compiled to obtain field data about the practicality of Elementary Mathematics Learning packages.

e. Questionnaire responses of students

Data on students' responses to the field trial activities were obtained through student questionnaire responses. While the level of mastery of students towards learning material that has been taught is intended as a main indicator to measure the effectiveness of the learning packages and models.

\section{Data analysis technique}

The results of the validation of experts and education practitioners for each component of the equipment, were analyzed by considering input, comments, suggestions and criticisms 
from various parties. Subsequent assessment, carried out by observing the process of lecturer activities.

Analysis of the results of observations of lecturer activities includes: (1) the average frequency of each activity category for each activity, (2) the percentage of each lecturer activity category, and (3) the average of each lecturer activity category for all Tri Dharma activities of PT. The activities that will be carried out are as follows; (1) recapitulate the results of observations of the implementation of the Learning packages, (2) find the average of each aspect of observation of each activity, (3) find the average of each aspect of observation for $t$ times the activity, (4) find the total mean (), and (5) determine the category of implementation every aspect or overall aspect by matching the average of each aspect or the total average with the predetermined categories.

The steps taken related to data analysis; (1) count the number of lecturers who give positive responses according to the aspects asked, then calculate the percentage, (2) determine the categories for positive lecturer responses by matching the percentage results with established criteria, and (3) if the results of the analysis show that the lecturers' responses not yet positive, then a revision of the model being developed is carried out.

The base score for the next activity is taken from the average base score in some previous activities. Quantitative data used descriptive statistics. While qualitative data will be used qualitative data analysis techniques by Miles and Huberman [3]

\section{Findings and Discussion}

The learning packages development process begins with the define stage, the design phase, the development stage, and the disseminate stage. The define phase starts with the front end analysis, student analysis, material analysis, task analysis, and formulation of learning objectives. In the front end analysis, the problem studied is the presence of manipulative media that can help prospective teachers in teaching mathematics in elementary school. The description of the characteristics of prospective teachers in the analysis of students shows that the level of knowledge and skills of teacher candidates is sufficient and already possessed to achieve learning objectives.

At the material analysis stage, the materials are determined: numbers and number systems, numbers, integers, and rational numbers, and FPB-KPK. This material is considered things that need to be mastered by prospective teachers in teaching basic number learning. Furthermore, at the task analysis stage, teacher candidates are expected to teach the material that has been determined. The skill required to teach number material is to use existing teaching aids about numbers. The final stage in define is formulating learning objectives; namely prospective teachers are able to: (a) master conceptual knowledge in learning numbers in elementary and (b) apply conceptual knowledge of learning numbers in elementary schools through the design and implementation of learning.

At the design stage, manipulative media is chosen. The manipulative media entered corresponds to the manipulative media categorized by Swan \& Marshall [4], namely: (a) Scales of numbers, (b) Cussenaire bars, (c) Abacus, (d) Unit Blocks, (e) Number Line Tools, (f) Number Cards, (g) Fraction Cards, (h) Circle fractions, and (i) Decimal Square Transparants. Furthermore, in this stage a selection of learning Packages formats is carried out, namely: a learning implementation plan (RPP), a student book (BPD), and a student worksheet (LKPD). The learning packages is adapted to the principles, characteristics and steps of learning Mathematics in a cooperative setting on number learning materials. 
The development phase is the stage to produce development products which are carried out through two steps, namely: (1) expert appraisal followed by revision, (2) developmental testing. At this stage a validation of the learning packages that has been developed is done. Validation results are obtained as follows (1) Learning Implementation Plan (RPP) has a good category and can be used with little revision, (2) Students' Books (BPD) have good categories and can be used with slight revisions, and (3) LKPD has categories good and can be used with slight revisions.

The learning Packages test was conducted at the Elementary School Teacher Education Study Program (PGSD), which was attended by 24 students / prospective teachers, 1 partner lecturer and 2 observers with different tasks, namely one person observing the activities of students in participating in learning and one person observing the ability of the lecturer in managing cooperative learning settings assisted by manipulative media. The trial is held 4 times in accordance with the learning implementation plan that was developed, carried out in the BC class 7.1 PGSD Study Program Academic Semester 2019/2020 on 18 August 2019 to 6 September 2019. In the learning process, students are grouped into 6 groups Each group consisted of 4 people. Heterogeneous division of groups based on Mathematics courses in the previous semester is an introduction to Basic Mathematics so that group abilities are relatively the same.

Data obtained from the test in the form of: student activity observation data, and learning achievement test data, are used to determine the effectiveness of learning packages, then data from observations of learning implementation and student response results to the learning process and learning packages are used to determine practicality of learning Packagess. Data obtained when testing the learning kit are analyzed, and the results are used as consideration for revising the learning kit into the final learning kit.

The test results of the learning outcomes were analyzed by the SPSS program using the One Sample t-test. Benchmark criteria are at a value of 70 which is the minimum achievement limit (completeness) of students who are considered to have graduated for a course. The results obtained are as follows:

Table 1. Descrptive Statistic Output

One-Sample Statistics

\begin{tabular}{|l|c|c|c|c|}
\hline & $\mathrm{N}$ & Mean & $\begin{array}{c}\text { Std. } \\
\text { Deviation }\end{array}$ & $\begin{array}{c}\text { Std. Error } \\
\text { Mean }\end{array}$ \\
\hline $\begin{array}{l}\text { Tes hasil belajar } \\
\text { Pembelajaran } \\
\begin{array}{l}\text { Media } \\
\text { Manipulatif }\end{array}\end{array}$ & 20 & 77.2500 & 9.79729 & 2.19074 \\
\hline
\end{tabular}


Tabel 2. Inferential Statistic Output

\begin{tabular}{|c|c|c|c|c|c|c|}
\hline \multicolumn{7}{|c|}{ One-Sample Test } \\
\hline & \multicolumn{6}{|c|}{ Test Value $=69.9$} \\
\hline & \multirow[b]{2}{*}{$\mathrm{t}$} & \multirow[b]{2}{*}{ df } & \multirow{2}{*}{$\begin{array}{l}\text { Sig. (2- } \\
\text { tailed) }\end{array}$} & \multirow{2}{*}{$\begin{array}{c}\text { Mean } \\
\text { Difference }\end{array}$} & \multicolumn{2}{|c|}{$\begin{array}{l}\text { 95\% Confidence Interval of } \\
\text { the Difference }\end{array}$} \\
\hline & & & & & Lower & Upper \\
\hline $\begin{array}{l}\text { Tes hasil belajar } \\
\text { Pembelajaran } \\
\text { Media } \\
\text { Manipulatif }\end{array}$ & 3.355 & 19 & .003 & 7.35000 & 2.7647 & 11.9353 \\
\hline
\end{tabular}

Based on Table 2, the probability value is $0.003<0.05$. Thus Ho's hypothesis which states that the average learning outcome is less than 70 is rejected. This means that the average elementary school teacher candidates exceeds 70 .

Based on observations of student activity shows that the majority of prospective teachers are active in learning, of the 24 students included in the category of active teacher candidates are 20 people or $83 \%$ and only 4 students (17\%) inactive. Thus it can be concluded that on average students are active students in participating in mathematics learning cooperative settings assisted by manipulative media

Based on the calculation of observational data on the overall implementation of learning in the category of "good". This is indicated by the average value of learning outcomes of each lesson plan. The average implementation of learning in RPP 1 is 4.4, the implementation of RPP 2 is 4.3: the implementation of RPP 3 is 4.4 and the implementation of RPP 4 is 4.5 so that the average learning achievement is 4.4 .

The results of the questionnaire responses of 24 students to the learning process and elementary school mathematics learning packages assisted by the cumuplative media were $91.67 \%$ of students responding happily to the subject matter, and the learning packages used, $83.3 \%$ of students responded happily to the Mathematical learning model assisted cooperative setting manipulative media. In addition, as many as $75 \%$ of students were happy with the way lecturers taught and $79.1 \%$ of students were happy with the learning atmosphere in class.

students who expressed interest in participating in mathematics learning were $83.3 \%$. According to $83.3 \%$ of students, also stated that learning with a cooperative setting assisted by manipulative media is more fun and easy to understand related to the basic concepts of addition, subtraction, multiplication and division, and can improve the pedagogy skills of the teacher candidates themselves. So the results of students' responses to the learning process and the learning packages of Mathematics in cooperative settings assisted by manipulative media are positive.

The learning packages developed by the researchers consisted of (1) Learning Implementation Plan (RPP), (2) Student Books, (3) Student Worksheets (LKPD). The initial development of the developed learning kit is called draft 1 . The learning kit is validated by experts. The results of the equipment validation obtained an average RPP with an average of 4.3 (good), Student's Book 4.4 (good), and Student Worksheet (LKPD) 4.2 (good). The average validation results for all developed learning packages are 4.3 (good). All validators provide valid evaluations, are very understandable and can be used with minimal revisions.

The learning kit is said to be effective if it meets the criteria of (1) the test of the prospective teacher's learning outcomes is complete, and (2) the student activity when participating in high learning. 77.24 and completeness test of learning outcomes test with a 
probability value of one sample t-test of 0.003 where this value is smaller than 0.05 , is in the area of rejection of $\mathrm{Ho}$, so $\mathrm{H} 1$ is accepted meaning the average value of elementary school teacher candidates exceeds the completeness limit.

In learning, students' activities are very necessary because without their activities, learning will not be meaningful. This is in line with Nurmala's research [5] which states that the activities of students are very influential on the test of learning outcomes. Based on observations of student activity shows that most students are active in learning, of the 24 students included in the category of active students there are 20 students (83\%), and only 4 students $(17 \%)$ inactive. Thus it can be concluded that the activeness of students is very high in participating in learning mathematics. This is also in line with the research of Amir [6] and Inawati [7] namely the use of manipulative media can motivate students' motivation in solving elementary mathematics problems. Elementary Mathematics learning packages assisted by manipulative media support more active learning in the classroom

The effectiveness test of the developed learning Packages has been fulfilled. This can be seen from (1) the student learning outcomes test is complete, (2) the activity of students when participating in learning is very high. The practicality of the developed learning Packages can be measured by the following criteria: (1) the level of implementation and the ability of the lecturer to manage learning with the learning Packages developed in the minimal category either, (2) students respond positively to the learning process and the mathematics learning Packages cooperative setting assisted by manipulative media.

The results of observations of the implementation of learning showed the implementation of learning took place well with an average of 4.4 , while the results of the questionnaire responses of students showed that of the 24 students there were $91.67 \%$ which was coupled with the learning process and elementary school mathematics learning packages assisted with cumuplative media, $83,3 \%$ of students responded happily to the Mathematical learning model of cooperative settings assisted by manipulative media. In addition, as many as $75 \%$ of students were happy with the way lecturers taught and $79.1 \%$ of students were happy with the learning atmosphere in class. Students who expressed interest in participating in mathematics learning amounted to 83.3

To test the practicality of the developed learning packages, it meets the following criteria: (1) the level of implementation and the ability of lecturers to manage learning with learning Packagess that are developed in either category, (2) students respond positively to the learning process and learning Packagess with cooperative learning models assisted by manipulative media., so it can be said that the practicality of the learning Packages is fulfilled.

Based on input from expert assessments and trials conducted, the results of the development of the final learning kit are as follows:

(1) The title of the Student Book (BPD), namely "learning Numbers in elementary school", is converted into numbers and learning in elementary school "

(2) The chapter is divided into two major parts namely Content Knowledge and Pedagogy Knowledge with the help of manipulative media.

(3) In Content Knowledge, the material presented is (a) numbers and number systems, (b) count numbers, (c) integers, (e) Fraction numbers, and (f) FPB-KPK. Whereas in the Pedagogy Knowledge, the material presented was (a) Enumeration Learning, (b) Learning of Round Numbers, (c) Learning of Fraction Numbers, and (e) Learning of FPB and KPK.

(4) In pedagogy knowledge, manipulative media used are (a) Scales of numbers, (b) Cussenaire Bars, (c) Abacus, (d) Unit Blocks, (e) Number Line Tools, (f) Number Cards, (g) ) Fraction Card, (h) Circle fraction, and (i) Decimal Square Transparrant. 
(5) In the Learning Implementation Plan (RPP), the selection of learning models is used with learning models with cooperative settings with learning using manipulative media.

(6) On the Student Worksheet (LKPD), arranged by displaying the steps of activities in using the intended teaching aids.

\section{Conclusion}

Based on the research results, the conclusions obtained are as follows:

(1) Development of learning packages with a modified 4-D model, starting from the front end analysis (Define), initial manufacturing of learning Packagess (Design), and testing (Develop). Implementation and desimination have not been carried out. Elementary mathematics learning packages assisted by manipulative media on number material are valid, effective, and practical to improve mathematical pedagogy skills of prospective and creative elementary school teachers.

(2) The effectiveness of learning Packagess meets the effective criteria by: (1) the prospective teacher learning outcomes are complete, and (2) student activities when participating in learning are high, the effectiveness of learning Packagess is seen from the results of descriptive and inferential statistics, namely the learning outcomes of prospective teachers show that the average the average was at 77.24 from the idela score of 100 and the completeness test of learning outcomes test with a probability value of one sample t-test of $0.003<0.05$, which means that the learning outcomes of students are complete.

Based on the conclusions obtained, suggestions were made as follows: (1) Further research needs to be done, which are verification and modification so that the learning packages produced are more optimal. (2) Mathematics learning packages assisted by manipulative media need to be developed also for other material, such as in the material of flat build, space, and statistics, because student responses and student activities when participating in learning are very high, so student achievement can increase.

\section{Reference}

[1] Muhsetyo, G., Krisnadi, E., \& Wahyuningrum, E. (2014). Pembelajaran matematika SD.

[2] Tiagarajan, S. DS; Semmel, dan MI; Semmel. 1974. Instructional Development for Training Center of Exceptional Children.

[3] Miles, M. B. D. A. (1992). A Michael Huberman. Analisis Data Kualitatif: Buku Sumber Tentang Metode-metode Baru.

[4] Swan, P., \& Marshall, L. (2010). Revisiting mathematics manipulative materials. Australian Primary Mathematics Classroom, 15(2), 13-19.

[5] Nurmala, D. A., Tripalupi, L. E., \& Suharsono, N. (2014). Pengaruh Motivasi Belajar dan Aktivitas Belajar Terhadap Hasil Belajar Akuntansi. Jurnal Pendidikan Ekonomi Undiksha, 4(1).

[6] Amir, A. (2014). Pembelajaran matematika SD dengan menggunakan media manipulatif. In FORUM PAEDAGOGIK Jurnal Pendidikan Agama Islam (Vol. 6, No. 01).

[7] Inawati, M. (2011). Meningkatkan minat mengenal konsep bilangan melalui metode bermain alat manipulatif. Jurnal Pendidikan, 16, 1-10. 